\title{
Kepuasan Pasien terhadap Layanan Puskesmas BLUD di Kota Semarang
}

Chriswardani Suryawati ${ }^{*}$, Nurhasmadiar Nandini ${ }^{*}$, Novia Handayani ${ }^{*}$

* Fakultas Kesehatan Masyarakat, Universitas Diponegoro, Semarang Email: chriswardani.suryawati@live.undip.ac.id

\section{ABSTRACT}

Primary Health Centre (PHC) is one of the public institution which have important role to provide health care services to the community. According to Regulation of Semarang Major no. 13 year 2016 about Governance Pattern of Local Public Service Institution (BLUD) of Puskesmas, since 2017 PHC in Semarang transformed into BLUD PHC which enable PHC to be more flexible, productive, efficient, and effective on managing their resources and finance. This research objective was to identify patient satisfaction of BLUD PHC in Semarang. This was quantitative research with cross-sectional design and research variables are tangible, reliability, responsiveness, assurance, empaty, dan patient's satisfaction. Respondents were 140 patients of BLUD PHC in Semarang City: Bulu Lor, Gayamsari, Pudakpayung, Bangetayu, Halmahera, Kedungmundu, dan Mangkang. Result showed that most of the patient satisfied with the health care services in PHC. From all of the indicators, more than
$80 \%$ respondents stated that they were satisfied with the services in PHC. The highest score was on responsiveness aspect, which $95.0 \%$ patient scored high on the PHC responsiveness. It could be because PHC already maximize their resources to provide high quality health care services.

Keywords: Primary Health Centre; Patient Satisfaction; BLUD

\section{PENDAHULUAN}

Puskesmas sebagai salah satu institusi pelayanan publik merupakan pemeran penting dalam upaya meningkatkan derajat kesehatan masyarakat. Puskesmas dituntut untuk dapat memberikan pelayanan yang bermutu dan terjangkau bagi masyarakat. Salah satu masalah yang dialami puskesmas dalam memberikan pelayanan sehingga pelayanannya tidak optimal adalah keterbatasan anggaran, alur birokrasi yang terlalu panjang, aturan pengelolaan keuangan yang menghambat. ${ }^{1}$

Permendagri Nomor 61 Tahun tentang Pedoman Teknis Pengelolaan Badan Layanan Umum Daerah (BLUD) juncto Permendagri No.79 tahun 2018 tentang Badan Layanan Umum Daerah adalah salah satu upaya pemerintah untuk meningkatkan kinerja institusi pelayanan 
publik dengan memberikan kewenangan lebih besar pada pengelolaan sumber dayanya terutama keuangan. ${ }^{2}$ Salah satu institusi pelayanan publik yang melakukan perubahan menjadi BLUD adalah puskesmas.

BLUD Puskesmas adalah Satuan Kerja Perangkat Daerah atau Unit Kerja pada Satuan Kerja Perangkat Daerah di lingkungan pemerintah daerah yang dibentuk untuk memberikan pelayanan kepada masyarakat berupa penyediaan barang dan/atau jasa yang dijual tanpa mengutamakan mencari keuntungan, dan dalam melakukan kegiatannya didasarkan pada prinsip efisiensi dan produktivitas. ${ }^{2}$ Berbagai persyaratan perlu dipenuhi oleh Puskesmas untuk

Puskesmas BLUD berpeluang untuk dapat meningkatkan pelayanannya serta produktivitas kerja pegawai. ${ }^{3}$ Puskesmas akan lebih fleksibel, produktif, efisien, dan efektif dalam mengelola keuangan dan sumber daya yang dimiliki. Pada tahun 2017, Pemerintah Kota Semarang melalui Dinas Kesehatan meresmikan semua puskesmas di Kota Semarang menjadi BLUD Puskesmas. Setelah menjadi Puskesmas BLUD, pola pengelolaan keuangan di puskesmas lebih fleksibel dan leluasa untuk menerapkan praktek bisnis yang sehat. Diharapkan puskesmas akan lebih leluasa untuk meningkatkan pelayanan kepada masyarakat. ${ }^{4}$

Memberikan pelayanan yang berkualitas adalah salah satu tuntutan masyarakat. Puskesmas dituntut memberikan pelayanan kesehatan yang bermutu, sesuai standar, dengan biaya pelayanan yang terjangkau sehingga akan meningkatkan kepuasan pasien. ${ }^{1}$ Kepuasan pasien adalah salah satu indikator untuk menilai keberhasilan puskesmas dalam memberikan pelayanan kesehatan. Penilaian kepuasan pasien BLUD Puskesmas penting dilakukan sebagai bahan evaluasi pelayanan Puskesmas sekaligus sebagai dasar untuk melakukan perbaikan dan peningkatan mutu layanan. Oleh karena itu penelitian ini dilakukan untuk mengidentifikasi kepuasan pasien Puskesmas BLUD di Kota Semarang.

\section{METODE PENELITIAN}

Penelitian ini adalah penelitian kuantitatif dengan desain cross-sectional. Penelitian dilakukan di enam Puskesmas di Kota Semarang yaitu Puskesmas Bulu Lor, Gayamsari, Pudakpayung, Bangetayu, Halmahera, Kedungmundu, dan Mangkang.

Populasi penelitian adalah seluruh pasien di enam Puskesmas tersebut. Sampel penelitian adalah 140 orang pasien pengguna jasa pelayanan pada enam puskesmas tersebut dijadikan responden penelitian dengan kuesioner sebagai instrumen penelitian. Variabel penelitian dikembangkan dari teori teori Servqual oleh Parasuraman ${ }^{5}$ yaitu tangible (kondisi fisik), reliability (kehandalan), responsiveness (ketanggapan), assurance (jaminan dan kepastian), empathy (empati) dan patient satisfaction (kepuasan pasien). Pengambilan data dilakukan pada bulan September - Oktober 2018.

Analisis data dilakukan secara deskriptif untuk mengidentifikasi karakteristik responden dan variablevariabel penelitian. Penelitian ini telah mendapatkan ethical clearance dari Komisi Etik Penelitian Fakultas Kesehatan Masyarakat No. 259/EA/KEPK-FKM/2018.

\section{HASIL DAN PEMBAHASAN}

Penilaian kepuasan pasien menggunakan kuesioner modifikasi teori Servqual. ${ }^{5}$ Penilaian kepuasan dilakukan berdasarkan indikator tangible (kondisi 
bukti fisik), reliability (kehandalan), responsiveness (ketanggapan), assurance (jaminan dan kepastian), empathy (empati), dan patient satisfaction (kepuasan pasien). Hal ini serupa dengan penelitian oleh Indrayathi, dkk mengenai penilaian persepsi masyarakat pengguna layanan Puskesmas Perawatan BLU di Kabupaten Gianyar. Pada penelitian tersebut persepsi masyarakat dinilai berdasarkan 5 dimensi mutu. $^{6}$

Hasil penelitian menujukkan bahwa mayoritas responden mereka mempunyai kartu JKN (BPJS Kesehatan) yaitu 87,9\% dan sebanyak $64,3 \%$ berstatus PBI (penerima bantuan iuran). Keberadaan JKN terbukti meningkatkan akses masyarakat (terutama miskin) kepada fasilitas kesehatan bila mereka sakit dan hal ini juga dibuktikan oleh beberapa penelitian lain. , $^{7}$

Sebelum menyusun hasil pengelompokkan variabel, dilakukan deskripsi pertanyaan untuk mengidentifikasi masing - masing variabel. Dengan batasan lebih dari $10 \%$ responden berpendapat "tidak" yang berarti didalam persepsi pasien hal yang ditanyakan adalah bermasalah maka pada variabel tangible (kondisi bukti fisik) ada beberapa hal yang dirasakan responden pasien masih perlu perbaikan yaitu parkir kendaraan belum tertib (11,4\%). Pada variabel reliability (kehandalan) lama waktu tunggu masih dikeluhkan responden baik ketika menunggu mendapatkan layanan pemeriksaan dokter $(30,7 \%)$ maupun lamanya waktu tunggu antrian pengambilan obat di loket obat $(22,1 \%)$ dan sebanyak $25,7 \%$ responden tidak tahu bila harus dirujuk ke rumah sakit, Puskesmas melakukannya sesuai prosedur. Pada variabel responsiveness (ketanggapan), beberapa hal yang masih dikeluhkan responden yaitu kecekatan petugas loket melayani resep dari pasien (10,0\%) yang kemudian dirasakan berpengarud pada lama waktu tunggu pengambilan obat di loket obat. Pada variabel assurance (jaminan dan kepastian) semua pendapat responden yang menyatakan "tidak" kurang dari 10\%. Pada variabel empathy (empati) dikeluhkan tidak adanya kotak saran yang dapat menampung saran dan keluhan pengguna layanan puskesmas (13,6\% repsonden menyatakan "tidak" dan 12,9\% menyatakan "tidak tahu") Pada variabel patient satisfaction (kepuasan pasien) dari semua pertanyaan yang diajukan sebanyak $90 \%$ atau lebih responden menyatakan puas dengan layanan puskesmas.

Tabel 1. Hasil Penilaian Kepuasan Pasien di BLUD Puskesmas Kota Semarang Tahun 2018

\begin{tabular}{lcccccccc}
\hline \multirow{2}{*}{ Indikator } & \multicolumn{10}{c}{ Kategori } \\
\cline { 2 - 9 } & \multicolumn{2}{c}{ Rendah } & \multicolumn{2}{c}{ Cukup } & \multicolumn{2}{c}{ Tinggi } & \multicolumn{2}{c}{ Total } \\
\cline { 2 - 9 } & $\mathrm{n}$ & $\%$ & $\mathrm{n}$ & $\%$ & $\mathrm{n}$ & $\%$ & $\mathrm{n}$ & $\%$ \\
\hline Tangible & 3 & 2.1 & 5 & 3.6 & 132 & 94.3 & 140 & 100 \\
Reliability & 7 & 5.0 & 21 & 15.0 & 112 & 80.0 & 140 & 100 \\
Responsiveness & 3 & 2.1 & 4 & 2.9 & 133 & 95.0 & 140 & 100 \\
Assurance & 3 & 2.1 & 13 & 9.3 & 124 & 88.6 & 140 & 100 \\
Empathy & 4 & 2.9 & 4 & 2.9 & 132 & 94.2 & 140 & 100 \\
Satisfaction & 5 & 3.6 & 11 & 7.9 & 124 & 88.5 & 140 & 100 \\
\hline \multicolumn{1}{c}{ Berdasarkan Tabel 1, terlihat bahwa } & \multicolumn{7}{c}{ tinggi pada penilaian kepuasan pelayanan di } \\
lebih dari 80\% responden memberikan nilai & \multicolumn{7}{c}{ Puskesmas BLUD. Pertanyaan yang dinilai }
\end{tabular}


pada aspek tangible meliputi kebersihan puskesmas dan lingkungan puskesmas, kerapihan, kenyamanan, penataan, penampilan petugas serta ruang pemeriksaan yang tertutup. Sesuai dengan beberapa penelitian sebelumnya yang menyatakan bahwa aspek tangible dinilai dari kondisi dan kebersihan ruang tunggu, ruang pemeriksaan, dan lain sebagainya. ${ }^{6,9}$

Lingkungan fasilitas pelayanan kesehatan yang nyaman merupakan salah satu layanan yang diharapkan (expected service) oleh pasien sebagai konsumen di Puskesmas, suatu pelayanan akan dinilai bermutu jika mampu memenuhi harapan konsumen. ${ }^{10}$ Penilaian yang tinggi pada aspek tangible menunjukkan bahwa kondisi lingkungan di Puskesmas sudah memenuhi harapan pasien.

Pada aspek reliability, dinilai mengenai ketepatan jam pelayanan puskesmas, proses pendataan pasien, proses antrian, proses pengambilan obat, proses rujukan, dan reliabilitas pelayanan di puskesmas secara umum. Sebesar $80 \%$ pasien memberikan nilai yang tinggi untuk aspek reliability. Penelitian sebelumnya telah menjelaskan bahwa aspek reliability memiliki hubungan yang signifikan terhadap kepuasan pasien, khususnya terkait ketepatan waktu pelayanan pasien. ${ }^{11}$

Pada aspek responsiveness menilai ketanggapan petugas administrasi, perawat, dan dokter. Terdapat 95\% responden memberikan nilai yang tinggi untuk aspek responsiveness. Hal ini menunjukkan bahwa ketanggapan petugas di Puskesmas sudah sangat baik. Penelitian sebelumnya menjelaskan bahwa aspek responsiveness memberikan pengaruh tidak langsung terhadap loyalitas pasien. ${ }^{12} \mathrm{Hal}$ ini menunjukkan bahwa penilaian yang tinggi pada aspek responsiveness adalah salah satu faktor pertimbangan pasien untuk melakukan kunjungan ulang ke Puskesmas.

Aspek assurance menilai reputasi puskesmas, persepsi pasien mengenai kompetensi dokter dan perawat, kesopanan, serta keramahan petugas administrasi dan tenaga kesehatan. Sebagian besar responden memberikan penilaian yang tinggi untuk aspek assurance (88.6\%). Beberapa penelitian membuktikan bahwa penilaian yang tinggi pada aspek kesopanan, keramahan, dan sikap lainnya yang digambarkan dalam assurance merupakan salah satu ciri pelayanan yang baik. ${ }^{13,14}$

Empathy menilai pelayanan petugas administrasi, perawat, dan dokter kepada pasien dalam memberikan informasi, memberikan kesempatan untuk bertanya dan berdiskusi. Selain itu juga menilai pengelolaan kritik dan saran pasien puskesmas. Hal ini sejalan dengan penelitian Handayani yang juga menilai aspek empathy melalui sikap petugas administrasi, dokter, serta perawat dalam memberikan pelayanan. $^{9}$ Perhatian, cara tenaga kesehatan memberikan penjelasan, kepedulian tenaga kesehatan yang tulus akan menimbulkan kepuasan pasien. ${ }^{15}$ Pasien sebagai konsumen Puskesmas yang mendapatkan empati dari petugas akan merasa puas dan akan cenderung memiliki keinginan untuk tetap mengkonsumsi jasa yang diberikan dan membentuk loyalitas pelanggan. ${ }^{16}$

Aspek reliability, responsiveness, assurance, dan empathy menggambarkan interaksi antara pemberi layanan kesehatan dan pasien. Penelitian sebelumnya menunjukkan bahwa interaksi antara pemberi layanan kesehatan dan pasien menunjukkan hubungan yang signifikan terhadap kepuasan pasien. Hal ini disebabkan karena dalam kualitas interaksi yang baik akan meningkatkan perceived 
customer value yang diterima pasien dan akan meningkatkan kepuasan pasien. ${ }^{17}$ Sejalan dengan pendapat Kotler dan Keller yang menjelaskan bahwa value yang tinggi didapatkan dari hubungan baik dan interaksi yang baik antara pemberi jasa dan pengguna jasa, dalam hal ini tenaga kesehatan di Puskesmas dan pasien. ${ }^{18}$

Penelitian sebelumnya juga menjelaskan bahwa aspek tangible, empathy, assurance, responsiveness, dan reliability memiliki pengaruh tidak langsung terhadap kepuasan pasien dengan variabel antara kepuasan pasien. ${ }^{12}$ Hal ini menunjukkan bahwa dalam memutuskan untuk menggunakan kembali pelayanan di suatu fasilitas pelayanan kesehatan, pasien akan mempertimbangkan lima aspek tersebut.

Handayani S meneliti kepuasan pasien Puskesmas Baturetno Kabupaten Wonogiri tahun 2015, dari semua variabel yang diteliti diperoleh nilai yang lebih rendah daripada penelitian ini. Dengan membandingkan harapan dan pengalaman yang menggambarkan tingkat kepuasan pasien terhadap pelayanan kesehatan dalam aspek berwujud 72,76\%, keandalan $72,09 \%$, empati $72,89 \%$, ketanggapan $72,88 \%$, dan jaminan $72,22 \%$, sementara itu tingkat kepuasan secara keseluruhan sebesar $72,58 \%{ }^{9}$

Secara umum, satisfaction menilai kepuasan umum pasien secara umum terhadap layanan administrasi, pelayanan oleh perawat, pelayanan oleh dokter, kondisi fisik puskesmas, proses administrasi puskesmas, mutu pelayanan puskesmas dan kesediaan pasien untuk merekomendasikan dan menggunakan ulang pelayanan kesehatan di puskesmas. Beberapa penelitian membuktikan bahwa penilaian mutu pelayanan menggunakan SERVQUAL memiliki pengaruh signifikan terhadap kepuasan pasien..$^{9,11,15,19,20}$ Sedangkan kepuasan pasien memiliki pengaruh langsung terhadap loyalitas pasien. Pasien yang merasa puas terhadap pelayanan di suatu pelayanan kesehatan cenderung akan melakukan kunjungan ulang dan memberikan rekomendasi untuk menggunakan pelayanan di fasilitas pelayanan kesehatan tersebut. ${ }^{12,16}$

\section{KESIMPULAN}

Penilaian kepuasan pasien di 6 Puskesmas BLUD di Kota Semarang menunjukkan bahwa sebagian besar pasien menunjukkan tingkat kepuasan yang tinggi terhadap pelayanan yang diberikan. Mutu layanan akan mempengaruhi kepuasan pasien, sedangkan kepuasan pasien akan mempengaruhi loyalitas pasien. Untuk itu penting bagi Puskesmas sebagai fasilitas pelayanan kesehatan untuk meningkatkan mutu layanannya untuk dapat meningkatkan loyalitas pasien.

Diharapkan Puskesmas akan terus meningkatkan kualitas pelayanannya khususnya pada aspek yang dinilai konsumen paling rendah yaitu aspek reliability dan assurance antara lain ketepatan jam pelayanan, memperpendek waktu antrian dan menunggu pelayanan untuk periksa dokter dan pengambilan obat di loket obat, begitu juga pembenahan perpakiran puskesmas serta tersedianya kota saran. Dengan adanya perubahan status menjadi BLUD Puskesmas maka terbukti puskesmas mampu meningkatkan layanannya karena dengan status BLUD Puskesmas dapat mengelola langsung pendapatannya dan melakukan inovasi untuk meningkatkan pelayanan kepada masyarakat. 


\section{UCAPAN TERIMA KASIH}

Penulis mengucapkan banyak terima kasih kepada Dinas Kesehatan Kota Semarang yang telah mendanai penelitian ini dan enam Puskesmas yang telah berpartisipasi pada proses penelitian.

\section{DAFTAR PUSTAKA}

1. Triprasetya AS, Trisnantoro L, Eka NLP. Analisis Kesiapan Penerapan Kebijakan Badan Layanan Umum Daerah (BLUD) Puskesmas di Kabupaten Kulon Progo (Studi Kasus di Puskesmas Wates dan Puskesmas Girimulyo II Kabupaten Kulon Progo). J Kebijak Kesehat Indones 2014; 3: 124-137.

2. Kementerian Dalam Negeri Republik Indonesia. Peraturan Menteri Dalam Negeri Nomor 61 Tahun 2007 Tentang Pedoman Teknis Pengelolaan Badan Layanan Umum Daerah (BLUD). 2007.

3. Kartini W. Pengaruh Pelaksanaan Kebijakan tentang Puskesmas dan Dukungan Sarana Prasarana terhadap Manajemen Pelayanan Kesehatan untuk Meningkatkan Produktivitas Kerja. J Publik J Ilm Bid Ilmu Adm Negara 2017; 11: 146-156.

4. Walikota Semarang. Peraturan Walikota Semarang Nomor 13 Tahun 2016 Tentang Pola Tata Kelola Badan Layanan Umum Daerah. 13/2016, Indonesia, 2016.

5. Parasuraman A, Valarie A. Z, Leonard L. B. Servqual : A MultipleItem Scale For Measuring Consumer Perc. J Retail 1988; 64: 12.

6. Indrayathi PA, Listyowati R,
Nopiyani NMS, et al. Mutu Pelayanan Puskesmas Perawatan yang Berstatus Badan Layanan Umum Daerah. Kesmas Natl Public Heal J 2014; 9: 164.

7. Irawan B, Ainy A. Analisis FaktorFaktor yang Berhubungan dengan Pemanfaatan Pelayanan Kesehatan pada Peserta Jaminan Kesehatan Nasional di Wilayah Kerja Puskesmas Payakabung, Kabupaten Ogan Ilir. J Ilmu Kesehat Masy 2018; 9: 189-197.

8. Rumengan DSS, Umbohu JM., Kandou G. Faktor-Faktor yang Berhubungan dengan Pemanfaatan Pelayanan Kesehatan Pada Peserta BPJS Kesehatan di Puskesmas Paniki Bawah Kecamatan Mapanget Kota Manado. JIKMU 2015; 5: 88100.

9. Handayani S. TINGKAT KEPUASAN PASIEN TERHADAP PELAYANAN KESEHATAN DI PUSKESMAS BATURETNO. Profesi (Profesional Islam Media Publ Penelit 2016; 14: 42.

10. Supriyanto S, Wulandari RD. Manajemen Mutu Pelayanan Kesehatan. Surabaya: Pohon Cahaya, 2010.

11. David, Hariyanti T, Widayanti Lestari E. Hubungan Keterlambatan Kedatangan Dokter terhadap Kepuasan Pasien di Instalasi Rawat Jalan. J Kedokt Brawijaya 2014; 28: 31-35.

12. Meesala A, Paul J. Service quality, consumer satisfaction and loyalty in hospitals: Thinking for the future. $J$ 
Retail Consum Serv 2018; 40: 261269.

13. Abdurahman, Junaidi, Aminuyati.

Analisis Kualitas Pelayanan Jasa Kesehatan (pada Pasien Rawat Inap Rumah Sakit Pendidikan Universitas Tanjungpura Pontianak). J Pendidik dan Pembelajaran Univ Tanjungpura 2017; 6: 1-22.

14. Chabibah AN. Kualitas Fungsional dan Kepuasan Pasien Terhadap Perawat dan Dokter Gigi di Rumah Sakit. J Adm Kesehat Indones 2018; 6: 143-148.

15. Sembel M, Opod H, Hutagalung BSP. GAMBARAN TINGKAT KEPUASAN PASIEN TERHADAP PERAWATAN GIGI DAN MULUT DI PUSKESMAS BAHU. $e$-GIGI; 2, http://ejournal.unsrat.ac.id/index.php /egigi/article/view/5855/5388 (2014).

16. Tanudjaya PK. Pengaruh Kualitas Pelayanan Klinik Gigi Terhadap Kepuasan dan Kepercayaan Pasien Sehingga Meningkatkan Keinginan untuk Berobat Kembali. J Manaj dan Pemasar jasa 2014; 7: 39-60.
17. Hakim MR. Persepsi Nilai Pelanggan dan Kepuasan di Klinik Swasta "X"di Surabaya. J Adm Kesehat Indones 2017; 5: 91-98.

18. Kotler, P.; Keller K. Marketing management. 2012. Epub ahead of print 2012.

DOI:

10.1108/ssmt.2001.21913cab.040.

19. da Costa GLG, Parwati CI, Susetyo J. Analisis Kualitas Pelayanan Rawat Inap Terhadap Kepuasan Pasien di Rumah Sakit Dr. Oen Surakarta dengan Menggunakan Metode Servqual dan QFD. $J$ REKAVASI 2016; 4: 16-20.

20. Taekab AH, Suryawati C, Kusumastuti W. ANALISIS PERSEPSI PASIEN TERHADAP MUTU PELAYANAN PUSKESMAS DAN HUBUNGANNYA DENGAN KEPUASAN PASIEN RAWAT JALAN DI PUSKESMAS LEYANGAN KABUPATEN SEMARANG TAHUN 2018. $J$ Kesehat Masy 2019; 7: 31-40. 